\title{
Factor and Rasch Analysis on COVID-19 Genetics Literacy Assessment Instrument
}

\author{
Ahmad Fauzi ${ }^{1 *}$, Muhammad Saefi ${ }^{2}$, Evi Kristiana ${ }^{3}$, Widi Cahya Adi ${ }^{4}$, Nurlita Lestariani ${ }^{5}$ \\ ${ }^{1}$ Universitas Muhammadiyah Malang, INDONESIA \\ 2 Universitas Negeri Malang, INDONESIA \\ 3 Universitas Islam Jember, INDONESIA \\ ${ }^{4}$ Universitas Islam Negeri Walisongo Semarang, INDONESIA \\ ${ }^{5}$ Universitas Islam Negeri Mataram, INDONESIA
}

Received 7 June 2021 - Accepted 10 October 2021

\begin{abstract}
During the COVID-19 pandemic, various applications of genetics were used as a basis for studying the origin of the virus to diagnosing patients with this disease. Student literacy about COVID-19 from the genetic aspect will strengthen them in dealing with misinformation in a society that rejects the existence of COVID-19. This study aimed to evaluate the COVID-19 genetics literacy instrument. The draft instrument consisting of 20 items was first distributed online to Biology Education students in Indonesia. The analysis was carried out after 400 respondents filled out the online form. Seven items were eliminated according to the results of CFA and EFA. There were 13 items comprising of three dimensions taken. The Rasch analysis shows that the instrument is reliable and has a separation index according to the recommendations. There was no misfit and its have good discriminating power. The three choices given in each item did not confuse the respondents. Therefore, the instrument was of good quality and could be used to evaluate respondents' genetics literacy for future studies.
\end{abstract}

Keywords: COVID-19 pandemic, hoax, misinformation, genetics understanding, scientific literation, SARS-CoV-2

\section{INTRODUCTION}

Genetics is considered the cornerstone of modern biology. An understanding of genetics can be used to understand all aspects of how living organisms function and evolve (Nurse \& Hayles, 2019). This biology's subdisciplinary has developed into an integral part of most biological research whose findings provide a significant impact on human life (Klug et al., 2012; Snustad \& Simmons, 2012). Genetics has been applied in plant breeding (Bernardo, 2020), forensic (Dumache \& Enache, 2016), drug development (Roses et al., 2014), and vaccine design (Castiblsanco \& Anaya, 2015). Genetics application also contribute to uncovering new species and new diseases (Phan, 2020).

During the COVID-19 pandemic, scientists have also applied various genetic methods to study the virus causing this disease and how to treat them. Referring to the report from researchers, like other coronaviruses, the genetic material of this virus is in the form of singlestranded RNA (Rahimi et al., 2021). Genetic studies have revealed the phylogenetic relationship of this virus to other coronaviruses (Tabibzadeh et al., 2021) as well as predicted the mutation and evolution behind the emergence of this new virus (Li et al., 2020). Studying the genes of the SARS-CoV-2, scientists were able to determine the function of each of these genes (Naqvi et al., 2020). They were also capable of designing primers and RT-PCR procedures to diagnose suspected COVID19 patients (Patankar \& Zambare, 2021; Torretta et al., 2021). Together with several pharmaceutical companies, scientists are also developing vaccines based on the SARS-CoV-2 genetic code (Borah et al., 2021). Hence, genetics literacy becomes one's basic knowledge in following science development and responding wisely

(c) 2021 by the authors; licensee Modestum. This article is an open access article distributed under the terms and conditions of the Creative Commons Attribution License (http://creativecommons.org/licenses/by/4.0/). 


\section{Contribution to the literature}

- The COVID-19 pandemic presents the usefulness of genetics in uncovering origins and diagnosing nongenetic hereditary diseases.

- Various developed genetics literacy assessment instrument is limited to measuring understanding of the basic concepts of genetics or genetic diseases.

- This study presents the EFA, CFA, and Rasch analysis results of a draft instrument assessing genetics literacy related to COVID-19.

to various natural phenomena. Therefore, genetics literacy is considered an important aspect of scientific literacy.

In the digital era, scientific literacy is needed to ward off hoaxes (Vraga et al., 2020). Misleading information, hoaxes, and even conspiracy theories are spread on social media, such as in Facebook (Ahmed et al., 2020), Twitter (Krittanawong et al., 2020), and WhatsApp (Bowles et al., 2020). Fake information can endanger people's lives since some misleading information make them ignore health advice (Barua et al., 2020; Roozenbeek et al., 2020). Many people accept and believe in the fake news and hoaxes on health issues and thereby, reducing their protective behavior (Lee et al., 2020; van der Linden et al., 2020). This is reflected in the current situation during the COVID-19 pandemic.

The misleading information in this pandemic can be in the form of rumors and conspiracy related to the origin of the virus that causes COVID-19 (Nie, 2020) until distorted understanding of vaccines (Bertin et al., 2020; Cornwall, 2020). Individuals' distrust of information related to COVID-19 cannot be separated from their declining trust in government and modern health (Freeman et al., 2020; Georgiou et al., 2020). In fact, all this misleading information can easily be refuted by understanding genetics. With genetics literacy, students can understand the virus mutation behind the emergence of new virus diseases, the performance of PCR in identifying the viral genes, the body's differences response when infected with a virus, as well as the principle of developing nucleic acid-based vaccines. Therefore, genetics literacy can become a bulwark against fake news in health.

\section{Genetics Literacy}

Genetic literacy is one focus of studies in the science education field which has begun to develop over the last decade. As a focus that has not been touched by the majority of researchers in the education field, there is no consensus among scholars on the definition of genetic literacy. No wonder, there are many definitions of what genetic literacy really is (Boerwinkel et al., 2017). When reviewing various publications that measure or develop genetic literacy instruments, some authors tend to position genetic literacy as knowledge of genetics, for example Bowling (2007). In his publications, he uses various references that discuss genetic knowledge as a literature review of genetic literacy. Bowling (2007) also defines genetic literacy as understanding genetic concepts and how these concepts relate to their lives. When referring to Boerwinkel et al. (2017), genetic literacy is part of scientific literacy. In this regard, other authors state that scientific literacy is not only limited to mastering science knowledge and attitudes, but also being aware of when and how they should be capable of using them (Stern \& Kampourakis, 2017). Therefore, the definition of genetic literacy should not be limited to a basic understanding of genetic concepts.

Several studies have also attempted to clarify what genetic literacy is and formulate components of genetic literacy from various perspectives. Shea et al. (2015) attempted to present a tri-part model for genetic literacy. In this model, genetic literacy consists of content knowledge use, argumentation quality, and the role of situational features in reasoning. On the other hand, Boerwinkel et al. (2017) describes genetic literacy as knowledge consisting of three aspects, namely conceptual (knowledge of genetic concepts), sociocultural (knowledge of the application of genetic technology and its implications), and epistemic (knowledge of the meaning of genetic information). In this regard, Stern and Kampourakis (2017) suggest that there are two pillars related to genetic literacy, namely understanding knowledge and practice from science content and using it in making decisions related to socioscientific issues. Meanwhile Chapman et al. (2019) has a simpler explanation. They state that genetic literacy is related to a person's ability to use scientific thinking for personal and social purposes related to genetics.

Genetic literacy can also be defined as a person's competence to understand, use, or respond to information about genetic phenomena, to the application of genetic technology faced by many people in everyday life (Duncan et al., 2009). Furthermore, the application of literacy becomes important in cases of socio-scientific issues when people are required to make decisions that can affect their lives (Stern \& Kampourakis, 2017). Therefore, someone is said to be genetically literate not only because they understand the concept of genetics, but also skills related to decision making in situations that involve the application of genetic technology (Cebesoy \& Oztekin, 2018).

Some researchers, such as Cebesoy and Oztekin (2018) use literacy instruments that refer to Bowling et al. 
(2008). In his paper, their genetic literacy instrument was developed based on six genetic concepts, namely nature of the genetic material, transmission, gene expression, gene regulation, evolution, and genetics \& society. Bowling et al.'s main source in determining the six basic concepts was the list of genetics content benchmarks identified by the American Society of Human Genetics studied by Hott et al. (2002). Chapman et al. (2017) used another genetic literacy instrument which was also developed based on the six concepts reported by Hott et al. (2002). Some researchers have also used or even developed instruments to measure the genetic literacy of their research subjects. The genetic literacy instrument used by Abrams et al. (2015) consists of three knowledge components, i.e., awareness knowledge (term familiarity), how to knowledge (practical skills), and principal knowledge (factual knowledge). On the other hand, the genetic literacy instrument used by Boerwinkel et al. (2017) also consists of several levels of knowledge, namely conceptual, sociocultural, and epistemic. From all these instruments, it is clear that the measurement of genetic literacy does not only access respondents' understanding of the basic concepts of genetics, but also their knowledge regarding how genetics-based science and technology development is used to solve human problems. From all these instruments, it is clear that the measurement of genetic literacy does not only access respondents' understanding of the basic concepts of genetics, but also their knowledge regarding how the development of genetics-based science and technology is implemented in various cases in human life.

\section{Research Rationale}

The importance of genetics literacy has been recognized by some researchers before the COVID-19 pandemic occurred. Several studies in the US have reviewed the science curriculum of primary and secondary education (Lontok et al., 2015) to higher education (McElhinny et al., 2014). Several other researchers emphasize the importance of genetics education in nursing education (Camak, 2016; DaackHirsch et al., 2013; Giarelli \& Reiff, 2012). In line with these studies, other researchers have also developed various genetics literacy assessment instruments, such as the genetics literacy assessment instrument for undergraduates (Bowling et al., 2008), Genetic Literacy and Attitudes Survey (Chapman, 2017), and Public Understanding and Attitudes towards Genetics and Genomics (Condit, 2010). Interestingly, in accordance with researches reviewing and raising the urgency of genetics education, these literacy instruments focus more on measuring respondents' literacy and understanding of the basic concepts of genetics, even though some of them are related to diseases and genetic testing. Furthermore, study that evaluate COVID-19 literacy is also very rare. Until now, there is only one study that explore the students COVID-19 literacy in Indonesian (Fauzi et al., 2020) and the study that focus on evaluating COVID-19 instrument is still limited on KAP questionnaire (Saefi et al., 2020b).

Due to the difficulty of finding instruments able to evaluate genetics literacy based on contextual phenomena during the COVID-19 pandemic, this study intends to develop and evaluate instrument for assessing COVID-19 genetics literacy. The significance of this study is to facilitate further researchers in the education and health domain in assessing genetics literacy. The measurements can be the basis for evaluating students' COVID-19 literacy levels from a genetics perspective. The lack of data related to genetics literacy can be a basis for follow-up and policymaking, and science and health education curriculum reformulation to respond to alarming situation of students who easily trust fake news in this pandemic.

\section{METHODS}

\section{Literature Review and Item Formulation}

The process of developing the questionnaire begins with identifying which genetic concepts will be covered by the instrument. Determination of these concepts is based on the benchmarks list of genetics content reported by Hott et al. (2002). Based on Hott et al. (2002), there are six genetic concepts measured, namely: a) nature of the genetic material, b) transmission, c) gene expression, d) gene regulation, e) evolution, and f) genetics and society. The main reason for Hott et al. (2002) in specifying the six concepts is that those concepts contribute to an understanding of life on Earth and enable students to make informed and responsible decisions about the personal and social implications of genetics. The determination of these concepts was also based on the results of a review of five leading introductory biology textbooks. Because the genetic literacy instrument evaluated in this study is literacy related to COVID-19, then these genetic concepts are applied to the SARS-CoV-2 virus or specifically the COVID-19 disease.

The second step was the identification of the information that should be included on the instrument. The themes included as the basis for identification relates to the COVID-19 literature from a genetics perspective. The themes cover the structure of the SARSCoV-2 genetic material, the genes in the SARS-CoV-2 genome, the mutations of SARS-CoV-2, and the genetic sequencing-based diagnosis of COVID-19. The literature review resulted in draft of genetics literacy about COVID-19 questionnaire consisting of 20 items. These 20 items were divided into ten correct statements and ten incorrect statements. Each question has three choices of responses, i.e., "yes", "no", and "I don't know". Table 1 
Table 1. List of concepts and statements contained in the COVID-19 genetic literacy instrument draft

\begin{tabular}{|c|c|c|c|}
\hline $\begin{array}{l}\text { Items } \\
\text { Number }\end{array}$ & Genetic Concepts & Statements & $\begin{array}{l}\text { Correct/ } \\
\text { Incorrect }\end{array}$ \\
\hline 1. & Nature of the genetic material & SARS-CoV-2 belongs to the DNA virus. & Incorrect \\
\hline 2. & Nature of the genetic material & SARS-CoV-2 genetic material is double-stranded. & Incorrect \\
\hline 3. & Evolution & Mutations are the origin of the emergence of SARS-CoV-2. & Correct \\
\hline 4. & Evolution & $\begin{array}{l}\text { The S gene is a highly variable gene in the coronavirus genome and } \\
\text { thus impacts the host viral diversity for this group of viruses. }\end{array}$ & Correct \\
\hline 5. & Genetics and society & $\begin{array}{l}\text { In the RT-PCR analysis, the diagnosis of a person infected by } \\
\text { COVID- } 19 \text { is based on the presence of the SARS-COV- } 2 \text { protein in } \\
\text { the patient's body. }\end{array}$ & Incorrect \\
\hline 6. & Transmission & $\begin{array}{l}\text { Similar to HIV, SARS-CoV-2 has genes that encode reverse } \\
\text { transcriptase (enzymes for the reverse transcription of RNA into } \\
\text { DNA). }\end{array}$ & Incorrect \\
\hline 7. & Gene regulation & $\begin{array}{l}\text { Differences in the regulation of certain gene expression in human } \\
\text { cells cause SARS-CoV-2 to infect cells in only a few tissues/organs. }\end{array}$ & Correct \\
\hline 8. & Transmission & $\begin{array}{l}\text { SARS-CoV-2 genetic material will replicate to produce new RNA } \\
\text { after the RNA performs reverse transcription into DNA. }\end{array}$ & Incorrect \\
\hline 9. & Evolution & $\begin{array}{l}\text { Based on phylogenetic analysis, SARS-CoV-2 is more closely } \\
\text { related to the coronavirus that infects bats than the virus that } \\
\text { causes Bird flu. }\end{array}$ & Correct \\
\hline 10. & Evolution & $\begin{array}{l}\text { Several strains of SARS-CoV-2 have emerged and are currently } \\
\text { spread in various parts of the world. }\end{array}$ & Correct \\
\hline 11. & Gene expression & $\begin{array}{l}\text { SARS-CoV-2's S gene encodes a protein that plays an important } \\
\text { role in the infection of the virus to human cells. }\end{array}$ & Correct \\
\hline 12. & Evolution & DNA viruses mutate more easily than RNA viruses. & Incorrect \\
\hline 13. & Gene expression & $\begin{array}{l}\text { In the body composed of various tissues and organs, only human } \\
\text { cells that have the ACE } 2 \text { gene can be infected by SARS-CoV-2, } \\
\text { while human cells in other organs that do not have this gene will } \\
\text { not be infected by SARS-CoV- } 2 \text {. }\end{array}$ & Incorrect \\
\hline 14. & Transmission & $\begin{array}{l}\text { SARS-CoV-2 genetic material will integrate with the target cell } \\
\text { genetic material after this virus infects the cell. }\end{array}$ & Incorrect \\
\hline 15. & Gene expression & $\begin{array}{l}\text { Human cells have genes that are able to code proteins that facilitate } \\
\text { the entry of SARS-CoV-2 into cells. }\end{array}$ & Correct \\
\hline 16. & Evolution & $\begin{array}{l}\text { Only missense and nonsense mutations identified in the SARS- } \\
\text { CoV-2 genome. }\end{array}$ & Incorrect \\
\hline 17. & Genetics and society & $\begin{array}{l}\text { ORF1ab is one of the segments of SARS-CoV-2 genetic material } \\
\text { which used as the basis for detection using RT-PCR. }\end{array}$ & Correct \\
\hline 18. & Nature of the genetic material & $\begin{array}{l}\text { Both the coding region and the noncoding region were found in } \\
\text { the SARS-CoV-2 genome. }\end{array}$ & Correct \\
\hline 19. & Genetics and society & $\begin{array}{l}\text { The mutations that occurred in the SARS-CoV- } 2 \text { genome only } \\
\text { occurred in the coding region, making it difficult for scientists to } \\
\text { make vaccines. }\end{array}$ & Incorrect \\
\hline 20. & Gene expression & $\begin{array}{l}\text { Genes } S, M, N \text {, and } \mathrm{E} \text { are the four genes that code for structural } \\
\text { proteins in SARS-CoV-2. }\end{array}$ & Correct \\
\hline
\end{tabular}

presents the twenty statements and information on the six underlying concepts.

Several items in instrument addressing the SARSCOV-2 nucleic acid segments and their reproduction. The spike (S), envelope (E), membrane (M), nucleocapsid (N) found in the SARS-COV-2 genome are included in this dimension. Being able to choose the right option on this item indicating that the respondent has started to develop into an independent learner who has a high curiosity. Related to the reproduction of genetic material, there is a statement dealing with the diagnosis of COVID-19. An accurate way of diagnosing someone infected by COVID-19 is by using RT-PCR (Patankar \& Zambare, 2021; Torretta et al., 2021). The RT-PCR identifies the presence of nucleic acid sequences possessed by certain living things or viruses to determine their presence (Kralik \& Ricchi, 2017; Zauli, 2020). Individual understanding of this information will make individuals understand how it works and trust the accuracy of the COVID-19 diagnostic test.

Furthermore, some items addressing the structure of the SARS-CoV-2 genetic material. In these items, respondents must identify the type of nucleic acids, the number of strands, and the mutation rate of SARS-CoV2. As a positive single-stranded RNA virus (Rahimi et al., 2021), the mutation rate of SARS-CoV-2 is quite high compared to other types of viruses (Carrasco-Hernandez et al., 2017). The structure of RNA is less stable than DNA and the non-complementary strands make nitrogenous base RNA more prone to mutations. In 
addition, the high error rate made by the polymerase enzyme in RNA virus replication is also a major factor in the high mutation rate of this type of virus (Duffy, 2018; Peck \& Lauring, 2018). It is not surprising that scientists have now discovered a variety of new SARS-CoV-2 strands from different countries (Burki, 2021). By having this understanding, one will not laugh and think scientists are making it up when they read the news of a new, more virulent strain, such as the British Variant, the B117 Virus.

The other items addressing the concept of evolution. Mutations that are essential to evolution and phylogenetic analysis that is a study of evolution are founded in these items. The researcher's report stating that SARS-CoV-2 is closely related to the coronavirus that infects bats is one of the statements written. Another statement deals with the compatibility of the protein encoded by the human gene with SARS-CoV-2. One of the widespread conspiracy theories on social media states that SARS-CoV-2 was created or as a result of a laboratory accident or intentionally produced as a biological weapon (Nie, 2020). In fact, based on genomic data and phylogenetic analyzes, the emergence of SARSCoV-2 is more likely due to a natural mutation from a coronavirus that infects other species (Andersen et al., 2020). This virus can infect the human body because the human gene encodes a receptor protein on the cell surface that matches the spike protein of SARS-COV-2 (Medina-Enríquez et al., 2020).

\section{Instrument Trial}

The respondents of this study were undergraduate students of Biology Education and Biology study programs throughout Indonesia. The data collection was by an online survey. The questionnaire draft was transformed into Google Form. The link was distributed through WhatsApp in August 2020. The minimum target of respondents was 400 undergraduate students.

\section{Data Analysis}

\section{Exploratory Factor Analysis (EFA)}

Before EFA was conducted, the sample adequacy was measure by Kaiser-Meyer-Olkin (KMO) test. Then, the observed correlation matrix was evaluated using Bartlett's test. After that, the EFA was conducted to determine item components and the dimension of questionnaire. The items with factor loading less than 0.5 were eliminated.

\section{Confirmatory Factor Analysis (CFA)}

The remained items were analyzed by using CFA. The fit item was produced the CFA was conducted. The model measurement was by statistic obtained from the Goodness-of-fit (GOF). Only item that had the
Standardized Regression Weight $(\lambda)$ higher than 0.5 were retained.

\section{Rasch analysis}

Before carrying out the Rasch analysis, a unidimensionality test was carried out. Then, the separation and reliability were determined based on the real values of RMSE. After that, the item fit was analyzed using infit and outfit MBSQ and ZSTD. Furthermore, the discriminant power was measured by PTMEA correlation coefficient. Subsequently, the clarity of response choices from the questionnaire items was analyzed using a diagnostic rating scale. Finally, a Wright Map was produced to describe the distribution of items based on the difficulty level of each item.

\section{The Example of Instrument Application}

After the instrument is developed and evaluated, the instrument can be applied to measure genetic literacy related to COVID-19. In addition to containing items that passed the CFA, EFA, and Rasch analysis, the distributed instrument contains several items that access respondents' demographic data, such as gender, age, year of study, institutional status, and status of residence. In this example, the data obtained are used to analyze the association between institutional status and the accuracy of students answering each literacy item.

First, the instrument was transformed into an online questionnaire using the Google Form platform. Then, the Google Form link was shared with the students. After all respondents have filled out the questionnaire, the survey results were downloaded into CSV format or into other types of files that can be processed in Microsoft Excel. Then, demographic data and literacy data were converted into numbers to facilitate the analysis process. In this example of instrument application, the selected demographic data was the status of the institution. The data on the institution status was converted to score 1 if the respondent's institution is public and score 2 if it is private. Then, the responses to literacy items were converted into scores of 1-3, where a score of 1 represents the respondent's ignorance of the information asked, a score of 2 represents an incorrect response, and a score of 3 represents an appropriate response. Next, the percentage of responses in each item is calculated to show the distribution of the answers. Finally, a chisquare test was performed for each item on the institutional status variable with a significance level of 0.05 .

\section{RESULTS}

\section{Descriptive Statistics}

The questionnaire items have mean score ranged from 1.40 to 2.46 and its standard deviation (SD) were $0.59-0.97$. Those SD not surpass 2.5 of the mean. All items 
Table 2. Exploratory factor analysis results

\begin{tabular}{|c|c|c|c|}
\hline \multirow{2}{*}{ Dimension and Item } & \multicolumn{3}{|c|}{ Component } \\
\hline & 1 & 2 & 3 \\
\hline \multicolumn{4}{|l|}{ Dimension 1} \\
\hline Item 18 & 0.756 & & \\
\hline Item 16 & 0.730 & & \\
\hline Item 19 & 0.658 & & \\
\hline Item 17 & 0.650 & & \\
\hline Item 20 & 0.623 & & \\
\hline Item 13 & 0.600 & & \\
\hline Item 8 & 0.520 & & \\
\hline \multicolumn{4}{|l|}{ Dimension 2} \\
\hline Item 1 & & 0.778 & \\
\hline Item 2 & & 0.758 & \\
\hline Item 12 & & 0.537 & \\
\hline \multicolumn{4}{|l|}{ Dimension 3} \\
\hline Item 9 & & & 0.777 \\
\hline Item 10 & & & 0.688 \\
\hline Item 15 & & & 0.656 \\
\hline Item 3 & & & 0.526 \\
\hline Eigenvalue & 6.427 & 1.831 & 1.170 \\
\hline$\%$ of variance & 32.126 & 9.157 & 5.848 \\
\hline Cumulative \% & 32.126 & 41.293 & 47.141 \\
\hline
\end{tabular}

was categorized as moderate correlation (the Pearson correlation coefficient were $0.44-0.67<0.80$ ).

\section{Exploratory Factor Analysis}

The result from the Measure of Sampling Adequacy using Kaiser-Meyer-Olkin Test of 400 respondents was
0.919 , categorized as "very good". Bartlett's test yielded $X^{2}(190)=2386.670, p<0.001$, indicating that the data can be used for further analysis. The Exploratory Factor Analysis results identified three dimensions, with a total variance explained of $47.14 \%$ (Table 2). From 20 items, six other items had factor loadings less than 0.5. Thus, they were eliminated.

\section{Confirmatory Factor Analysis}

From 400 respondents, the results of the confirmatory factor analysis using the correlated model (Figure 1) and the hierarchy model (Figure 2) resulted in a good Goodness-of-fit (GOF). The details are presented in Table 3. Only one item (Item 16) has Standardized Regression Weights $(\lambda)$ below 0.50 . Therefore, it was eliminated.

\section{Rasch Analysis}

The minimum variance explained resulting from the unidimensionality test of 80 respondents' data is $39.5 \%$. Because the percentage was greater than 30, the assumption of unidimensionality was met.

\section{Reliability and separation}

The separation person value and item reached 1.63 (accepted) and 4.48 (very good), subsequently. The person reliability value and item as high as 0.73

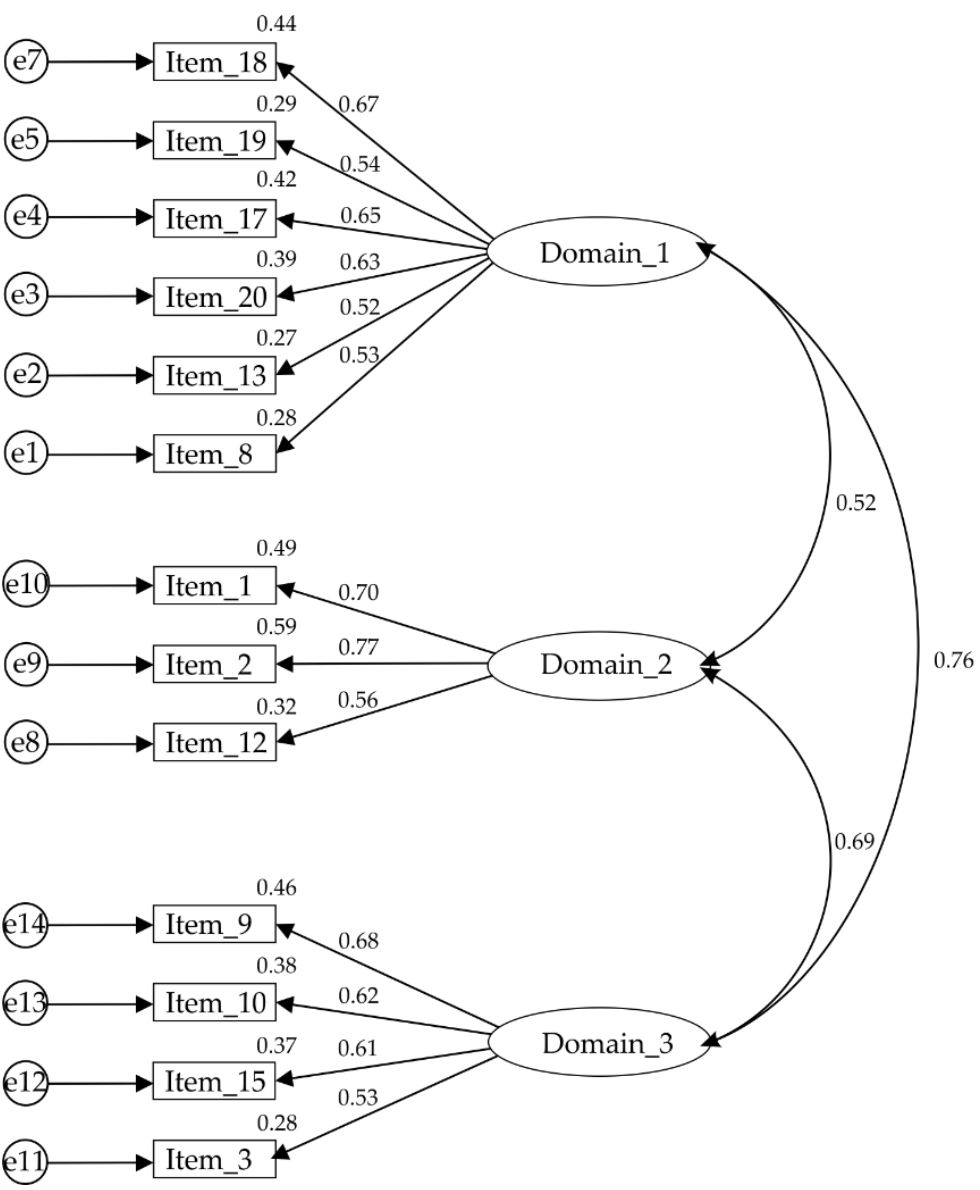

Figure 1. Correlated model 
Figure 2. Hierarchy model

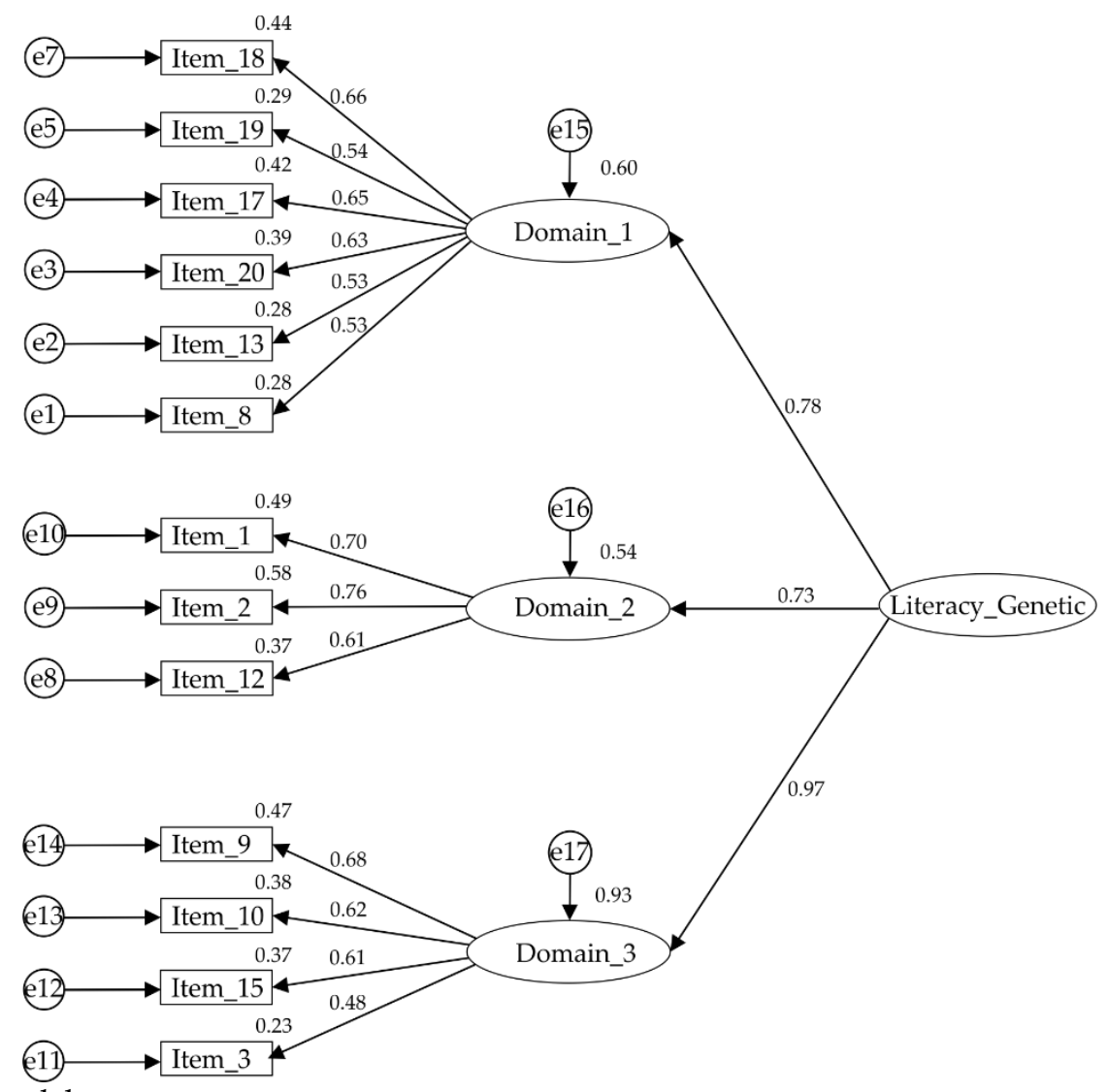

Table 3. The Goodness-of-fit (GOF) statistics

\begin{tabular}{lccccccc}
\hline Model & $\chi^{2} / \mathrm{df}$ & RMSEA & SRMR & CFI & GFI & AGFI & TLI \\
\hline Correlated & 2.479 & 0.061 & 0.035 & 0.930 & 0.946 & 0.921 & 0.920 \\
Hierarchy & 2.510 & 0.062 & 0.036 & 0.927 & 0.944 & 0.919 & 0.910 \\
\hline
\end{tabular}

Table 4. CR, AVE, and a on 12 items and 3 dimensions

\begin{tabular}{|c|c|c|c|c|}
\hline \multirow{2}{*}{ Dimension and Items } & \multicolumn{4}{|c|}{ Criteria } \\
\hline & $\lambda$ & $\mathrm{CR}$ & AVE & $\mathrm{a}$ \\
\hline \multicolumn{2}{|l|}{ Dimension 1} & \multirow{7}{*}{0.74} & \multirow{7}{*}{0.32} & \multirow{7}{*}{0.77} \\
\hline Item 18 & 0.663 & & & \\
\hline Item 19 & 0.535 & & & \\
\hline Item 17 & 0.647 & & & \\
\hline Item 20 & 0.526 & & & \\
\hline Item 13 & 0.525 & & & \\
\hline Item 8 & 0.528 & & & \\
\hline \multicolumn{2}{|l|}{ Dimension 2} & \multirow{4}{*}{0.73} & \multirow{4}{*}{0.48} & \multirow{4}{*}{0.71} \\
\hline Item 1 & 0.669 & & & \\
\hline Item 2 & 0.759 & & & \\
\hline Item 12 & 0.611 & & & \\
\hline \multicolumn{2}{|l|}{ Dimension 3} & \multirow{5}{*}{0.70} & \multirow{5}{*}{0.37} & \multirow{5}{*}{0.70} \\
\hline Item 9 & 0.683 & & & \\
\hline Item 10 & 0.619 & & & \\
\hline Item 15 & 0.609 & & & \\
\hline Item 3 & 0.530 & & & \\
\hline Total & & & & 0.85 \\
\hline
\end{tabular}

(moderate) and 0.95 (special). On the other hand, Cronbach's alpha value reached 0.75 (good) (Table 5).

The MNSQ infit value of questionnaire items ranges between $0.47-1.21$ with the mean value of 1.02 and P.SD of 0.23 (Table 6). The MNSQ outfit value ranged between
0.57 to 1.43 , with the mean value of 1.03 with a P.SD of 0.20 . Meanwhile, the ZSTD infit ranged between -5.89 to 1.48 with the mean value of 0.10 and P.SD reaches 2.10. The ZSTD outfit ranged between -2.97 to 1.6 with an average of 0.00 and P.SD of 1.10. Therefore, all items were accepted. 
Table 5. Summary of reliability and separation analysis

\begin{tabular}{lc}
\hline Analysis & Results \\
\hline Person reliability & 0.73 \\
Person separation & 1.63 \\
Item reliability & 0.95 \\
Item separation & 4.48 \\
Cronbach's alpha & 0.75 \\
\hline
\end{tabular}

Table 6. Item fit analysis of questionnaire

\begin{tabular}{lccccc}
\hline Items & Infit MNSQ & Infit ZSTD & Outfit MNSQ & Outfit ZSTD & PTMEA Corr \\
\hline 11 & 1.21 & 1.48 & 1.43 & 1.66 & 0.48 \\
9 & 1.26 & 1.40 & 1.11 & 0.88 & 0.49 \\
5 & 1.13 & 0.69 & 1.24 & 0.68 & 0.53 \\
3 & 1.20 & 1.13 & 1.16 & 0.63 & 0.50 \\
10 & 1.19 & 1.56 & 1.11 & 0.75 & 0.52 \\
13 & 1.18 & 1.60 & 1.11 & 0.22 & 0.54 \\
6 & 1.16 & 1.24 & 1.03 & 0.30 & 0.56 \\
7 & 1.06 & 0.56 & 1.04 & 0.01 & 0.42 \\
8 & 0.93 & -0.53 & 0.99 & -0.57 & 0.46 \\
1 & 0.89 & -0.81 & 0.89 & -0.92 & 0.50 \\
2 & 0.85 & -1.38 & 0.83 & -0.73 & 0.52 \\
42 & 0.71 & -2.38 & 0.57 & -2.97 & 0.43 \\
\hline Mean & 0.47 & -5.89 & 1.03 & 0.00 & 0.54 \\
\hline P.SD & 1.02 & -0.10 & 0.20 & 1.10 & \\
\hline
\end{tabular}

Table 7. The results of diagnostic rating scale

\begin{tabular}{lccccc}
\hline Scale & Andrich Threshold & Observed count $n(\%)$ & Observed average & Infit & Outfit \\
\hline 1 & None & $412(35)$ & -0.76 & 0.98 & 0.99 \\
2 & 0.13 & $265(23)$ & 0.13 & 0.93 & 0.91 \\
3 & -0.13 & $493(42)$ & 0.87 & 1.04 & 1.13 \\
\hline
\end{tabular}

\section{Discriminant power}

The determination of discriminatory power of the questionnaire is based on the PTMEA Corr (Table 6). The analysis result showed that the lowest score was found on item number $11(0.42)$; meanwhile, the highest score was on item 6 (0.56). Therefore, all items had PTMEA Corr higher than 0.40 .

\section{Diagnostic rating scale}

Based on the observed average, the value ascends from negative to positive. There was a value increase between first, second, and third option. Furthermore, based on the Andrich threshold, the value ascends from none to negative, then to positive (Table 7). This result shows that the option given to respondents are valid. The finding is strengthened with a graphical analysis representing the response function showing the recommended pattern (Figure 3).

\section{Wright map}

The Wright Map is presented in Figure 4. Based on the Wright Map, item 18 was the easiest and 9 was the most difficult to answer.

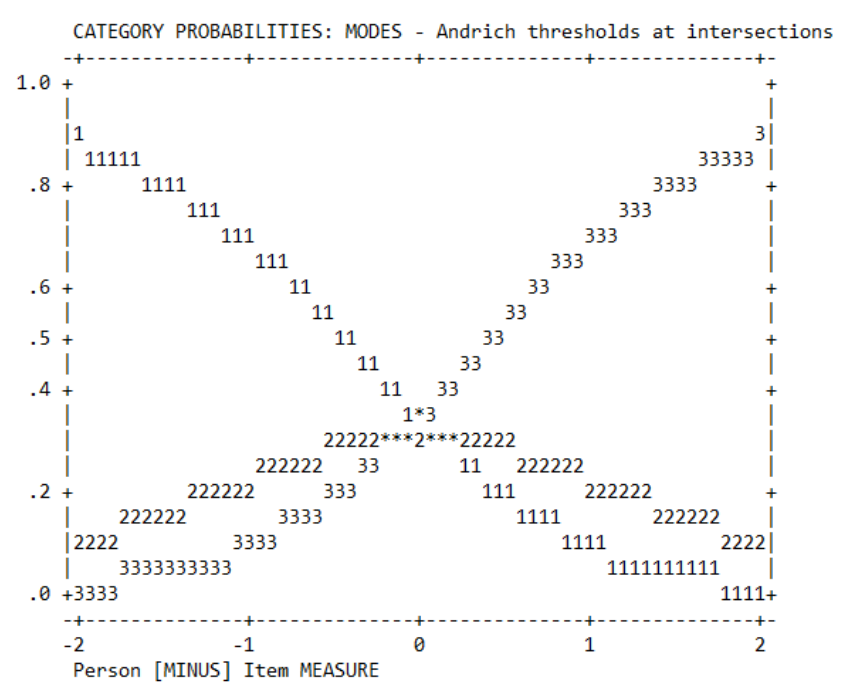

Figure 3. Category response curve

\section{The Example of Instrument Application}

The literacy instrument has been filled out by 250 students consisting of 117 students from public universities and 133 students from private universities. The distribution of the percentage of responses to each item and the results of the chi-square test to analyze the association between institutional status and response accuracy are presented in Table 8 . Based on Table 8, the 


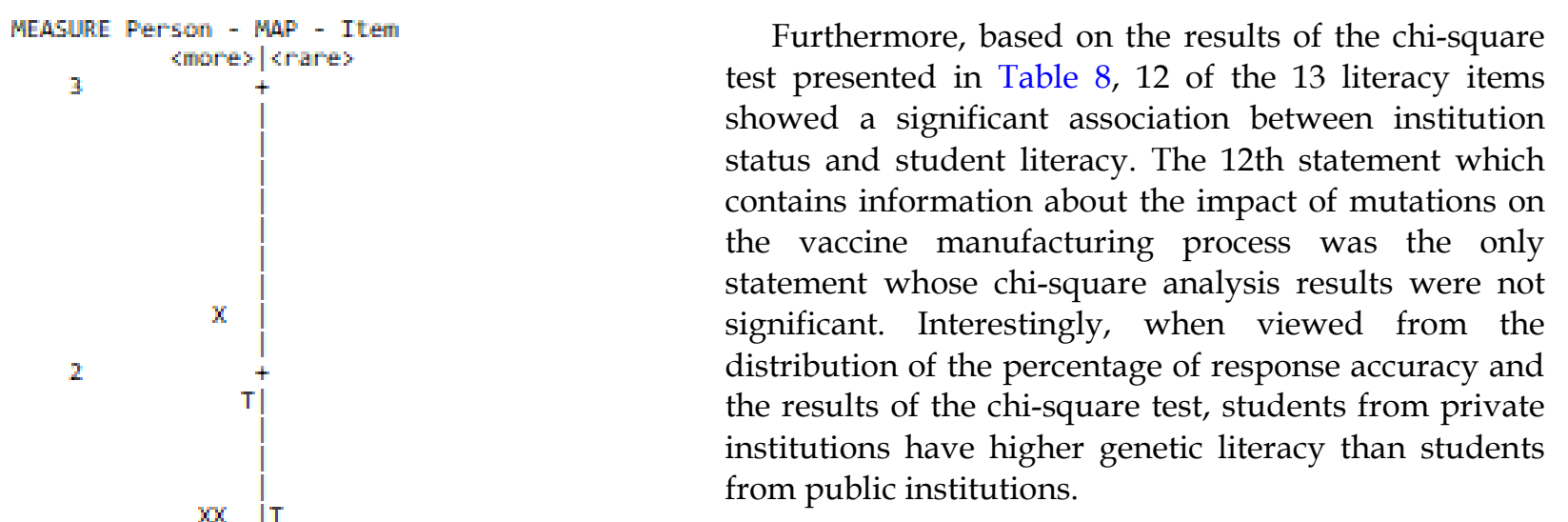

\section{DISCUSSION}

The high level of misinformation and the ease of being influenced by hoaxes is an indication of low literacy in the community. Someone who is illiterate will be easily deceived and influenced by misinformation. On the other hand, literacy has a major role to counter misinformation (Howell \& Brossard, 2021). Science literate citizens can filter out which information is in line with science and which is not (Sharon \& Baram-Tsabari, 2020). Furthermore, if the basics of scientific concepts are firmly held, individuals can refute misinformation that is illogical and inconsistent with scientific evidence. Those who have strong literacy about the concepts and applications of science will also be easier to convince the people around them if those people believe in hoaxes or do not believe in the presence of a new disease.

The emergence of new virus variants, molecularbased disease diagnosis, and the development of a COVID-19 vaccine are all related to the application of genetics. Therefore, one of the literacies that need to be empowered to tackle misinformation, hoaxes, and conspiracies related to COVID-19 is genetic literacy related to COVID-19. With good genetic literacy, students can also become agents who can straighten the understanding of the surrounding community. Student literacy regarding the type of SARS-CoV-2 genetic material and its replication process is needed as a basis for discussions about the existence of COVID-19 as a new disease that many people still don't believe in. Students' literacy regarding mutation, evolution, and phylogenetic can be their basis for convincing others regarding the emergence of new coronavirus variants as well as the emergence of various mutant strains of SARSCoV-2. Furthermore, their knowledge of the basic concepts and principles of molecular detection of the presence of viruses based on genetic material can be used as a basis for students to counteract public mistrust about the presence of new viruses and the diagnosis of COVID-19 patients.

Information on COVID-19 from a genetic perspective, as well as some other genetic knowledge, were outlined in the draft instrument of the genetics literacy questionnaire, which was tested for validity and gets the most incorrect answers. 
Table 8 . The results of the chi-square test between students' institutional status and student responses in each item

\begin{tabular}{|c|c|c|c|c|c|c|}
\hline \multirow{2}{*}{ Item } & \multirow{2}{*}{ Institution } & \multicolumn{3}{|c|}{ Percentage of each Response $(\%)$} & \multirow{2}{*}{$x^{2}$} & \multirow{2}{*}{ p-value } \\
\hline & & Do not know & Incorrect Response & Correct Response & & \\
\hline \multirow[t]{2}{*}{1} & Public & 33.3 & 35.0 & 31.6 & 23.573 & $<0.001$ \\
\hline & Private & 9.0 & 41.4 & 49.6 & & \\
\hline \multirow[t]{2}{*}{2} & Public & 49.6 & 26.5 & 23.9 & 31.23 & $<0.001$ \\
\hline & Private & 16.5 & 42.9 & 40.6 & & \\
\hline \multirow[t]{2}{*}{3} & Public & 38.5 & 17.1 & 44.4 & 43.905 & $<0.001$ \\
\hline & Private & 9.8 & 6.0 & 84.2 & & \\
\hline \multirow[t]{2}{*}{4} & Public & 47.0 & 44.4 & 8.5 & 21.441 & $<0.001$ \\
\hline & Private & 19.5 & 66.9 & 13.5 & & \\
\hline \multirow[t]{2}{*}{5} & Public & 27.4 & 7.7 & 65.0 & 29.912 & $<0.001$ \\
\hline & Private & 4.5 & 3.0 & 92.5 & & \\
\hline \multirow[t]{2}{*}{6} & Public & 38.5 & 4.3 & 57.3 & 20.179 & $<0.001$ \\
\hline & Private & 14.3 & 3.0 & 82.7 & & \\
\hline \multirow[t]{2}{*}{7} & Public & 35.0 & 47.9 & 17.1 & 10.976 & 0.004 \\
\hline & Private & 22.6 & 42.9 & 34.6 & & \\
\hline \multirow[t]{2}{*}{8} & Public & 61.5 & 23.1 & 15.4 & 23.219 & $<0.001$ \\
\hline & Private & 32.3 & 48.9 & 18.8 & & \\
\hline \multirow[t]{2}{*}{9} & Public & 33.3 & 13.7 & 53.0 & 18.012 & $<0.001$ \\
\hline & Private & 13.6 & 8.3 & 78.0 & & \\
\hline \multirow[t]{2}{*}{10} & Public & 81.2 & 6.0 & 12.8 & 23.756 & $<0.001$ \\
\hline & Private & 53.4 & 6.9 & 39.7 & & \\
\hline \multirow[t]{2}{*}{11} & Public & 76.1 & 6.0 & 17.9 & 16.281 & $<0.001$ \\
\hline & Private & 51.9 & 16.8 & 31.3 & & \\
\hline \multirow[t]{2}{*}{12} & Public & 58.1 & 33.3 & 8.5 & 4.865 & 0.088 \\
\hline & Private & 44.4 & 45.9 & 9.8 & & \\
\hline \multirow[t]{2}{*}{13} & Public & 61.5 & 6.8 & 31.6 & 22.506 & $<0.001$ \\
\hline & Private & 34.6 & 3.8 & 61.7 & & \\
\hline Mean & & 37.2 & 23.4 & 39.4 & & \\
\hline
\end{tabular}

reliability in this study. The study required an initial EFA analysis due to the instrument was not based on the other questionnaire which already had a clear dimension (Tavakol \& Wetzel, 2020). Based on EFA, six items have loading factors were not sufficient, therefore, those items were eliminated. On the other hand, based on CFA, one item must be eliminated as its $\lambda$ was not sufficient. The analysis also evaluate the level of data based on the proposed model (Alavi et al., 2020; Tavakol \& Wetzel, 2020). The analysis showed that the remaining items could be classified into three dimensions and produced a model with good GOF.

After factor analysis were conducted, Rasch analysis was carried out. The analysis was designed to validate the questionnaire items (Golino et al., 2014; Müller et al., 2015). Based on Rasch analysis, the remaining items in the questionnaire had good reliability and can be implemented in the field (Bond \& Fox, 2007; Gerbing \& Anderson, 1988). All items did not have any misfit, so, no items that leading to an unprecise respond by a competent respondent (Boone, 2016). Based on the PTMEA Correlation, the discriminatory power of the questionnaire was also good (Bond \& Fox, 2007). The three responses option was also was good condition. Therefore, the questionnaire and all items in the instrument had quality as recommended and appropriate to measure the genetics literacy about COVID-19.

This instrument is able to analyze students' abilities in applying the concepts of genetics. The results obtained from the assessment can be taken into consideration for curriculum reformulation and genetics course design to optimize genetic competence and encourage students to be lifelong learners. By having such competence, students can protect themselves from misinformation to conspiracy theories that are not in line with the development of science, especially those related to genetics. With their knowledge and belief in the truth and scientific developments, their positive attitude towards scientific findings will increase (Saefi et al., 2020a). It is expected that students will enlighten people who do not learn science and those who are not enlightened by scientific truth.

The existence of genetic literacy instruments also has significance for science education, especially biology education. Genetics is often considered the core of biology. However, even though it is positioned as a branch of biology that underlies various other branches, Genetics is included in the material that is the most difficult for students to understand, both high school students and college students (Fauzi et al., 2021). Genetics also be a biological concept that more often have misconception when compared with other 
biological concepts (Gusmalini et al., 2020; K1lıç et al., 2016). Furthermore, students with good mastery of genetics will easily understand various other biological concepts (Nurse \& Hayles, 2019). The reason is that various biological concepts, such as evolution, cell division, and the immune response are closely related to genetics. Therefore, the measurement of genetic literacy is an important effort to measure how strong students' mastery of biological concepts is and to measure the quality of the biology education curriculum in an educational institution.

The presence of genetic literacy instruments related to COVID-19 can also be the basis for evaluating whether education has been able to direct students to face the pandemic. Based on the genetic literacy data measured in the instrument developed in this study, educators can identify which genetic topics need to be strengthened so that students are ready to straighten out the understanding of the surrounding community when the next pandemic occurs. This is important because the public's lack of understanding and distrust about the disease will be a big obstacle for the government in tackling a pandemic or new disease.

Furthermore, this paper has also demonstrated how to apply the instruments that have been evaluated in this study. In addition to those exemplified in this paper, the use of this instrument can also be used to fulfill several purposes or analyze several other conditions. Other researchers can conduct a chi-square test using other demographic variables to analyze the existence of significant associations between literacy levels and these demographics, such as length of study, gender, and type of college. Researchers can also involve students from various study programs, such as biology study programs, biology education, health, science, and nonscience programs. Kruskal-Wallis analysis can be implemented to analyze whether there are significant differences between groups of students with their literacy level. In addition, these demographic variables and other conditions can also be collected and positioned as predictors for regression analysis so that researchers can analyze what conditions are significantly related to the level of genetic literacy of students related to COVID19. The findings of this study can be used to analyze what conditions have a positive role in student literacy. These findings can also be used as a basis for evaluating the science curriculum and analyzing student literacy on scientific phenomena that occur in their daily lives.

Apart from having significant urgency, the instrument analyzed in this study is unique compared to other genetics literacy assessment instruments. There has been little development of genetics literacy instruments and if there are some, they are with almost the same characteristics. Several instruments focus their items on assessing respondents' understanding of genetic concepts (Bowling et al., 2008; Fitzgerald-Butt et al., 2016; Smith et al., 2008; Todd \& Romine, 2016). Some other instruments attempt to measure respondents' literacy related to genetic diseases, such as the PUGGS instrument (Condit, 2010) and the REAL-G instrument (Erby et al., 2008). In this study, the genetics literacy assessment instrument does not measure the basic concepts of genetics or genetic diseases, but rather scientific reports and the use of genetics in pandemic caused by non-genetic diseases. This instrument becomes important since it raises the issue of the latest global phenomenon that has raided all countries and is still happening in 2021.

However, although the questionnaire evaluated in this study have a good result, several notes can become concern as basis to design the other research. First, further studies may involve more respondents to have more proper Rasch model. More samples will result in more satisfying Rasch model (Ismail et al., 2020). Beside that, the greater number of respondents will strengthen the analyzed parameter (He \& Wheadon, 2013; A. B. Smith et al., 2008). Further research is also recommended to develop genetic literacy instruments that can also access students' literacy about the role of proteins in genetic expression. Although proteins are not genetic material, they are involved as components that regulate the genetic expression of many genes. However, many students have difficulty understanding the involvement of proteins in trait determination mechanisms (HaskelIttah \& Yarden, 2017; Haskel-Ittah et al., 2020; Thörne et al., 2013). Therefore, to ensure and evaluate student literacy more thoroughly, this concept also needs to be accessed.

\section{CONCLUSION}

The present study has evaluated the questionnaire measuring the genetics literacy about COVID-19. Both factor and Rasch analysis have confirmed the items' accuracy in constructing the questionnaire. After conducting CFA and EFA, the instrument remains 13 items that can classified into three dimensions. The instrument had reliability and separation value as recommended. The remain items have no misfit and had good discriminatory power. The items have three response options ("yes", "no", and "I don't know"), which has good result in diagnosis rating scale analysis.

Based on all analysis were carried out, the instruments are recommended for further usage in educational research. The instrument may help the educator and the other researcher to evaluates the students' literacy about COVID-19 from genetics perspective. The utilization of the instrument can be the basis for government or education institution to reformulate the curriculum in this digital era that overwhelmed with misinformation.

Author contributions: All authors have sufficiently contributed to the study, and agreed with the results and conclusions.

Funding: No funding source is reported for this study. 
Acknowledgements: We would like to express our deepest gratitude to the LPPI Universitas Muhammadiyah Malang for the support in the process of publication of this research. The gratitude is also addressed to lecturers from various study programs in several universities in facilitating data collection for this research.

Declaration of interest: No conflict of interest is declared by authors.

\section{REFERENCES}

Abrams, L. R., McBride, C. M., Hooker, G. W., Cappella, J. N., \& Koehly, L. M. (2015). The many facets of genetic literacy: Assessing the scalability of multiple measures for broad Use in survey research. PLOS ONE, 10(10), e0141532. https:// doi.org/10.1371/journal.pone.0141532

Ahmed, N., Shahbaz, T., Shamim, A., Shafiq Khan, K., Hussain, S. M., \& Usman, A. (2020). The COVID-19 infodemic: A quantitative analysis through Facebook. Cureus, 12(11), 1-9. https:/ / doi.org/10.7759/cureus.11346

Alavi, M., Visentin, D. C., Thapa, D. K., Hunt, G. E., Watson, R., \& Cleary, M. (2020). Chi-square for model fit in confirmatory factor analysis. Journal of Advanced Nursing, 76(9), 2209-2211. https: / / doi.org/10.1111/jan.14399

Andersen, K. G., Rambaut, A., Lipkin, W. I., Holmes, E. C., \& Garry, R. F. (2020). The proximal origin of SARS-CoV-2. Nature Medicine, 26(4), 450-452. https:/ / doi.org/10.1038/s41591-020-0820-9

Barua, Z., Barua, S., Aktar, S., Kabir, N., \& Li, M. (2020). Effects of misinformation on COVID-19 individual responses and recommendations for resilience of disastrous consequences of misinformation. Progress in Disaster Science, 8, 100119. https:/ / doi.org/10.1016/j.pdisas.2020.100119

Bernardo, R. (2020). Reinventing quantitative genetics for plant breeding: something old, something new, something borrowed, something BLUE. Heredity, 125(6), 375-385. https://doi.org/10.1038/s41437020-0312-1

Bertin, P., Nera, K., \& Delouvée, S. (2020). Conspiracy beliefs, rejection of vaccination, and support for hydroxychloroquine: A Conceptual replicationextension inc the COVID-19 pandemic context. Frontiers in Psychology, 11(September), 1-9. https: / / doi.org/10.3389/fpsyg.2020.565128

Boerwinkel, D. J., Yarden, A., \& Waarlo, A. J. (2017). Reaching a consensus on the definition of genetic literacy that is required from a Twenty-FirstCentury citizen. Science $\mathcal{E}$ Education, 26(10), $1087-$ 1114. https:/ / doi.org/10.1007/s11191-017-9934-y

Bond, T., \& Fox, C. M. (2007). Applying the Rasch Model: Fundamental measurement in the human sciences (2nd ed.). Lawrence Erlbaum Associates, Inc.

Boone, W. J. (2016). Rasch analysis for instrument development: Why, when, and how? CBE Life
Sciences

Education

15(4)

https:/ / doi.org/10.1187/cbe.16-04-0148

Borah, P., Deb, P. K., Al-Shar'i, N. A., Dahabiyeh, L. A., Venugopala, K. N., Singh, V., Shinu, P., Hussain, S., Deka, S., Chandrasekaran, B., \& Jaradat, D. M. M. (2021). Perspectives on RNA vaccine candidates for COVID-19. Frontiers in Molecular Biosciences, 8, 635245.

https:/ / doi.org/10.3389/fmolb.2021.635245

Bowles, J., Larreguy, H., \& Liu, S. (2020). Countering misinformation via WhatsApp: Preliminary evidence from the COVID-19 pandemic in Zimbabwe. PLOS ONE, 15(10 October), 1-11. https:/ / doi.org/10.1371/journal.pone.0240005

Bowling, B. V. (2007). Development, evaluation, and use of a genetic literacy concept inventory for undergraduates [Doctoral dissertation], University of Cincinnati. https:/ / etd.ohiolink.edu/apexprod/rws_etd/sen d_file/send?accession=ucin1185456791\&dispositio $\mathrm{n}=$ inline

Bowling, B. V., Acra, E. E., Wang, L., Myers, M. F., Dean, G. E., Markle, G. C., Moskalik, C. L., \& Huether, C. A. (2008). Development and evaluation of a genetics literacy assessment instrument for undergraduates. Genetics, 178(1), 15-22. https:/ / doi.org/10.1534/genetics.107.079533

Burki, T. (2021). Understanding variants of SARS-CoV2. The Lancet, 397(10273), 462. https:/ / doi.org/10.1016/S0140-6736(21)00298-1

Camak, D. J. (2016). Increasing importance of genetics in nursing. Nurse Education Today, 44, 86-91. https:/ / doi.org/10.1016/j.nedt.2016.05.018

Carrasco-Hernandez, R., Jácome, R., López Vidal, Y., \& Ponce de León, S. (2017). Are RNA viruses candidate agents for the next global pandemic? A review. ILAR Journal, 58(3), 343-358. https:/ / doi.org/10.1093/ilar/ilx026

Castiblanco, J., \& Anaya, J.-M. (2015). Genetics and vaccines in the era of personalized medicine. Current Genomics, 16(1), 47-59. https://doi.org/ $10.2174 / 1389202916666141223220551$

Cebesoy, U. B., \& Oztekin, C. (2018). Genetics literacy: Insights from science teachers' knowledge, attitude, and teaching perceptions. International Journal of Science and Mathematics Education, 16(7), 1247-1268. https://doi.org/10.1007/s10763-0179840-4

Chapman, R. (2017). Genetic Literacy And Attitudes Survey (IGLAS): International population-Wide assessment instrument. In The European Proceedings of Social \& Behavioural Sciences (pp. 45-66). https://doi.org/10.15405/epsbs.2017.12.6

Chapman, R., Likhanov, M., Selita, F., Zakharov, I., Smith-Woolley, E., \& Ko- vas, Y. (2017). Genetic Literacy and Attitudes Survey (iGLAS): 
International population-wide assessment instrument. The European Proceedings of Social $\mathcal{E}$ Behavioural Sciences EpSBS, 33(6), 45-66. https:/ / doi.org/10.15405/epsbs.2017.12.6

Chapman, R., Likhanov, M., Selita, F., Zakharov, I., Smith-Woolley, E., \& Kovas, Y. (2019). New literacy challenge for the twenty-first century: genetic knowledge is poor even among well educated. Journal of Community Genetics, 10(1), 73-84. https: / / doi.org/10.1007/s12687-018-0363-7

Condit, C. M. (2010). Public understandings of genetics and health. Clinical Genetics, 77(1), 1-9. https:/ / doi.org/10.1111/j.1399-0004.2009.01316.x

Cornwall, W. (2020). Officials gird for a war on vaccine misinformation. Science, 369(6499), 14-15. https:/ / doi.org/10.1126/science.369.6499.14

Daack-Hirsch, S., Driessnack, M., Hanish, A., Johnson, V. A., Shah, L. L., Simon, C. M., \& Williams, J. K. (2013). "Information is information": a public perspective on incidental findings in clinical and research genome-based testing. Clinical Genetics, 84(1), 11-18. https:/ / doi.org/10.1111/cge.12167

Duffy, S. (2018). Why are RNA virus mutation rates so damn high? PLOS Biology, 16(8), e3000003. https:// doi.org/10.1371/journal.pbio.3000003

Dumache, R., \& Enache, A. (2016). Molecular Genetics and its Applications in Forensic Sciences. In Forensic Analysis - From Death to Justice. InTech. https://doi.org/10.5772/63530

Duncan, R. G., Rogat, A. D., \& Yarden, A. (2009). A learning progression for deepening students' understandings of modern genetics across the 5 th- 10 th grades. Journal of Research in Science Teaching, 46(6), 655-674. https://doi.org/10.1002/ tea.20312

Erby, L. H., Roter, D., Larson, S., \& Cho, J. (2008). The rapid estimate of adult literacy in genetics (REAL$\mathrm{G):}$ A means to assess literacy deficits in the context of genetics. American Journal of Medical Genetics Part A, 146A(2), 174-181. https://doi.org/10.1002/ ajmg.a.32068

Fauzi, A., Husamah, H., Miharja, F. J., Fatmawati, D., Permana, T. I., \& Hudha, A. M. (2020). Exploring COVID-19 literacy level among biology teacher candidates. Eurasia Journal of Mathematics, Science and Technology Education, 16(7), em1864. https:/ / doi.org/10.29333/ ejmste/8270

Fauzi, A., Rosyida, A. M., Rohma, M., \& Khoiroh, D. (2021). The difficulty index of biology topics in Indonesian Senior High School: Biology undergraduate students' perspectives. JPBI (Jurnal Pendidikan Biologi Indonesia), 7(2), 149-158. https:/ / doi.org/10.22219/jpbi.v7i2.16538

Fitzgerald-Butt, S. M., Bodine, A., Fry, K. M., Ash, J., Zaidi, A. N., Garg, V., Gerhardt, C. A., \& McBride,
K. L. (2016). Measuring genetic knowledge: A brief survey instrument for adolescents and adults. Clinical Genetics, 89(2), 235-243. https:/ / doi.org/10.1111/cge.12618

Freeman, D., Waite, F., Rosebrock, L., Petit, A., Causier, C., East, A., Jenner, L., Teale, A.-L., Carr, L., Mulhall, S., Bold, E., \& Lambe, S. (2020). Coronavirus conspiracy beliefs, mistrust, and compliance with government guidelines in England. Psychological Medicine, 1-13. https:/ / doi.org/10.1017/S0033291720001890

Georgiou, N., Delfabbro, P., \& Balzan, R. (2020). COVID19-related conspiracy beliefs and their relationship with perceived stress and pre-existing conspiracy beliefs. Personality and Individual Differences, 166, 110201.

https:/ / doi.org/10.1016/j.paid.2020.110201

Gerbing, D. W., \& Anderson, J. C. (1988). An Updated Paradigm for Scale Development Incorporating Unidimensionality and Its Assessment. Journal of Marketing Research, 25(2), 186-192. https: / / doi.org/10.1177/002224378802500207

Giarelli, E., \& Reiff, M. (2012). Genomic literacy and competent practice. Nursing Clinics of North America, 47(4), 529-545. https://doi.org/10.1016/ j.cnur.2012.07.006

Golino, H. F., Gomes, C. M. A., Commons, M. L., \& Miller, P. M. (2014). The construction and validation of a developmental test for stage identification: Two exploratory studies. Behavioral Development Bulletin, 19(3), 37-54. https:/ / doi.org/10.1037/h0100589

Gusmalini, A., Wulandari, S., \& Zulfarina. (2020). Identification of misconceptions and causes of student misconceptions on genetics concept with CRI method. Journal of Physics: Conference Series, 1655, 012053. https://doi.org/10.1088/17426596/1655/1/012053

Haskel-Ittah, M., \& Yarden, A. (2017). Toward bridging the mechanistic gap between genes and traits by emphasizing the role of proteins in a computational environment. Science $\mathcal{E}$ Education, 26(10), 11431160. https:/ / doi.org/10.1007/s11191-017-9927-x

Haskel-Ittah, M., Duncan, R. G., Vázquez-Ben, L., \& Yarden, A. (2020). Reasoning about genetic mechanisms: Affordances and constraints for learning. Journal of Research in Science Teaching, 57(3), 342-367. https:/ / doi.org/10.1002/tea.21595

He, Q., \& Wheadon, C. (2013). The effect of sample size on item parameter estimation for the partial credit model. International Journal of Quantitative Research in Education, 1(3), 297-315. https: / / doi.org/10.1504 /IJQRE.2013.057692

Hott, A. M., Huether, C. A., McInerney, J. D., Christianson, C., Fowler, R., Bender, H., Jenkins, J., 
Wysocki, A., Markle, G., \& Karp, R. (2002). Genetics content in introductory biology courses for nonscience majors: Theory and practice. BioScience, 52(11), 1024-1035. https://doi.org/10.1641/00063568(2002)052[1024:GCIIBC]2.0.CO;2

Howell, E. L., \& Brossard, D. (2021). (Mis)informed about what? What it means to be a science-literate citizen in a digital world. Proceedings of the National Academy of Sciences, 118(15), e1912436117. https:// doi.org/10.1073/pnas.1912436117

Ismail, N. E., Jimam, N. S., Dapar, M. L. P., \& Ahmad, S. (2020). Validation and Reliability of Healthcare Workers' Knowledge, Attitude, and Practice Instrument for Uncomplicated Malaria by Rasch Measurement Model. Frontiers in Pharmacology, 10, 1521. https:// doi.org/10.3389/fphar.2019.01521

Kılıç, D., Taber, K. S., \& Winterbottom, M. (2016). A cross-national study of students' understanding of genetics concepts: Implications from similarities and differences in England and Turkey. Education Research International, 2016(c), 1-14. https:// doi.org/10.1155/2016/6539626

Klug, W. S., Cummings, M. R., Spencer, C. A., \& Palladino, M. A. (2012). Concepts of Genetics (10th ed.). Benjamin Cummings.

Kralik, P., \& Ricchi, M. (2017). A basic guide to Real Time PCR in microbial diagnostics: Definitions, parameters, and everything. Frontiers in Microbiology, 8, 108. https://doi.org/10.3389/ fmicb.2017.00108

Krittanawong, C., Narasimhan, B., Virk, H. U. H., Narasimhan, H., Hahn, J., Wang, Z., \& Tang, W. H. W. (2020). Misinformation dissemination in twitter in the COVID-19 era. The American Journal of Medicine, 133(12), 1367-1369. https://doi.org/ 10.1016/j.amjmed.2020.07.012

Lee, J. J., Kang, K. A., Wang, M. P., Zhao, S. Z., Wong, J. Y. H., O'Connor, S., Yang, S. C., \& Shin, S. (2020). Associations between COVID-19 misinformation exposure and belief with COVID-19 knowledge and preventive behaviors: cross-sectional online study. Journal of Medical Internet Research, 22(11), 113. https:// doi.org/10.2196/22205

Li, T., Liu, D., Yang, Y., Guo, J., Feng, Y., Zhang, X., Cheng, S., \& Feng, J. (2020). Phylogenetic supertree reveals detailed evolution of SARS-CoV-2. Scientific Reports, 10(1), 22366. https://doi.org/10.1038/ s41598-020-79484-8

Lontok, K. S., Zhang, H., \& Dougherty, M. J. (2015). Assessing the genetics content in the next generation science standards. PloS One, 10(7), $\mathrm{e} 0132742$.

https:// doi.org/10.1371/journal.pone.0132742

McElhinny, T. L., Dougherty, M. J., Bowling, B. V., \& Libarkin, J. C. (2014). The Status of Genetics
Curriculum in Higher Education in the United States: Goals and Assessment. Science and Education, 23(2), 445-464. https://doi.org/10.1007/s11191012-9566-1

Medina-Enríquez, M. M., Lopez-León, S., CarlosEscalante, J. A., Aponte-Torres, Z., Cuapio, A., \& Wegman-Ostrosky, T. (2020). ACE2: the molecular doorway to SARS-CoV-2. Cell \& Bioscience, 10(1), 148. https:/ / doi.org/10.1186/s13578-020-00519-8

Müller, S., Kohlmann, T., \& Wilke, T. (2015). Validation of the adherence barriers questionnaire - An instrument for identifying potential risk factors associated with medication-related non-adherence. BMC Health Services Research, 15(1), 153. https:// doi.org/10.1186/s12913-015-0809-0

Naqvi, A. A. T., Fatima, K., Mohammad, T., Fatima, U., Singh, I. K., Singh, A., Atif, S. M., Hariprasad, G., Hasan, G. M., \& Hassan, M. I. (2020). Insights into SARS-CoV-2 genome, structure, evolution, pathogenesis and therapies: Structural genomics approach. Biochimica et Biophysica Acta (BBA) Molecular Basis of Disease, 1866(10), 165878. https:// doi.org/10.1016/j.bbadis.2020.165878

Nie, J.-B. (2020). In the shadow of biological warfare: conspiracy theories on the origins of COVID-19 and enhancing global governance of biosafety as a matter of urgency. Journal of Bioethical Inquiry, 17(4), 567-574. https://doi.org/10.1007/s11673-020$10025-8$

Nurse, P., \& Hayles, J. (2019). Using genetics to understand biology. Heredity, 123(1), 4-13. https:// doi.org/10.1038/s41437-019-0209-z

Patankar, R. S., \& Zambare, V. P. (2021). Development of RT-PCR based diagnosis of SARS-CoV-2. In Biotechnology to Combat COVID-19. IntechOpen. https:// doi.org/10.5772/intechopen.96823

Peck, K. M., \& Lauring, A. S. (2018). Complexities of viral mutation rates. Journal of Virology, 92(14), e0103117. https:/ / doi.org/10.1128/JVI.01031-17

Phan, T. (2020). Genetic diversity and evolution of SARSCoV-2. Infection, Genetics and Evolution, 81(February), 104260. https://doi.org/10.1016/ j.meegid.2020.104260

Rahimi, A., Mirzazadeh, A., \& Tavakolpour, S. (2021). Genetics and genomics of SARS-CoV-2: A review of the literature with the special focus on genetic diversity and SARS-CoV-2 genome detection. Genomics, 113(1), 1221-1232. https://doi.org/ 10.1016/j.ygeno.2020.09.059

Roozenbeek, J., Schneider, C. R., Dryhurst, S., Kerr, J., Freeman, A. L. J., Recchia, G., Van Der Bles, A. M., \& Van Der Linden, S. (2020). Susceptibility to misinformation about COVID-19 around the world: Susceptibility to COVID misinformation. 
Royal Society Open Science, 7(10), 201199. https:/ / doi.org/10.1098/rsos.201199

Roses, A. D., Saunders, A. M., Lutz, M. W., Zhang, N., Hariri, A. R., Asin, K. E., Crenshaw, D. G., Budur, K., Burns, D. K., \& Brannan, S. K. (2014). New applications of disease genetics and pharmacogenetics to drug development. Current Opinion in Pharmacology, 14, 81-89. https:/ / doi.org/10.1016/j.coph.2013.12.002

Saefi, M., Fauzi, A., Kristiana, E., Adi, W. C., Muchson, M., Setiawan, M. E., Islami, N. N., Ningrum, D. E. A. F., Ikhsan, M. A., \& Ramadhani, M. (2020a). Survey data of COVID-19-related knowledge, attitude, and practices among Indonesian undergraduate students. Data in Brief, 31, 105855. https://doi.org/10.1016/j.dib.2020.105855

Saefi, M., Fauzi, A., Kristiana, E., Adi, W. C., Muchson, M., Setiawan, M. E., Islami, N. N., Ningrum, D. E. A. F., Ikhsan, M. A., \& Ramadhani, M. (2020b). Validating of knowledge, attitudes, and practices questionnaire for prevention of COVID-19 infections among undergraduate students: A RASCH and factor analysis. Eurasia Journal of Mathematics, Science and Technology Education, 16(12), em1926. https:/ / doi.org/10.29333/ejmste/ 9352

Sharon, A. J., \& Baram-Tsabari, A. (2020). Can science literacy help individuals identify misinformation in everyday life? Science Education, 104(5), 873-894. https://doi.org/10.1002/sce.21581

Shea, N. A., Duncan, R. G., \& Stephenson, C. (2015). A tri-part model for genetics literacy: Exploring undergraduate student reasoning about authentic genetics dilemmas. Research in Science Education, 45(4), 485-507. https://doi.org/10.1007/s11165014-9433-y

Smith, A. B., Rush, R., Fallowfield, L. J., Velikova, G., \& Sharpe, M. (2008). Rasch fit statistics and sample size considerations for polytomous data. BMC Medical Research Methodology, 8(1), 33. https: / / doi.org/10.1186/1471-2288-8-33

Smith, M. K., Wood, W. B., \& Knight, J. K. (2008). The genetics concept assessment: A new concept inventory for gauging student understanding of genetics. CBE Life Sciences Education, 7(4), 422-430. https:/ / doi.org/10.1187/cbe.08-08-0045

Snustad, D. P., \& Simmons, M. J. (2012). Principles of genetics. Wiley.
Stern, F., \& Kampourakis, K. (2017). Teaching for genetics literacy in the post-genomic era. Studies in Science Education, 53(2), 193-225. https:/ / doi.org/10.1080/03057267.2017.1392731

Tabibzadeh, A., Esghaei, M., Soltani, S., Yousefi, P., Taherizadeh, M., Safarnezhad Tameshkel, F., Golahdooz, M., Panahi, M., Ajdarkosh, H., Zamani, F., \& Karbalaie Niya, M. H. (2021). Evolutionary study of COVID-19, severe acute respiratory syndrome coronavirus 2 (SARS-CoV-2) as an emerging coronavirus: Phylogenetic analysis and literature review. Veterinary Medicine and Science, 7(2), 559-571. https://doi.org/10.1002/vms3.394

Tavakol, M., \& Wetzel, A. (2020). Factor analysis: A means for theory and instrument development in support of construct validity. International Journal of Medical Education, 11, 245-247. https://doi.org/ 10.5116/ijme.5f96.0f4a

Thörne, K., Gericke, N. M., \& Hagberg, M. (2013). Linguistic challenges in Mendelian Genetics: Teachers' talk in action. Science Education, 97(5), 695-722. https:// doi.org/10.1002/sce.21075

Todd, A., \& Romine, W. L. (2016). Validation of the learning progression-based assessment of Modern Genetics in a college context. International Journal of Science Education, 38(10), 1673-1698. https:/ / doi.org/10.1080/09500693.2016.1212425

Torretta, S., Zuccotti, G., Cristofaro, V., Ettori, J., Solimeno, L., Battilocchi, L., D'Onghia, A., Bonsembiante, A., Pignataro, L., Marchisio, P., \& Capaccio, P. (2021). Diagnosis of SARS-CoV-2 by RT-PCR using different sample sources: Review of the literature. Ear, Nose $\mathcal{E}$ Throat Journal, 100(2_suppl), 131S-138S. https:/ / doi.org/10.1177/ 0145561320953231

van der Linden, S., Roozenbeek, J., \& Compton, J. (2020). Inoculating against fake news about COVID-19. Frontiers in Psychology, 11(October), 1-7. https:/ / doi.org/10.3389/fpsyg.2020.566790

Vraga, E. K., Tully, M., \& Bode, L. (2020). Empowering users to respond to misinformation about COVID19. Media and Communication, 8(2), 475-479. https:/ / doi.org/10.17645/mac.v8i2.3200

Zauli, D. A. G. (2020). PCR and Infectious Diseases. In Synthetic Biology - New Interdisciplinary Science. IntechOpen.

https:/ / doi.org/10.5772/intechopen.85630

\section{http://www.ejmste.com}

